\title{
SOCIO-ECONOMIC PROFILE OF THE LOW INCOME AND POOR COMMUNITIES IN KUALA LUMPUR CITY, MALAYSIA
}

Md. Wahid Murad

Tutor

Business School, Business School

School of Management

University of South Australia

South Australia, Australia

Md. Mahadi Hasan ${ }^{1}$

Senior Lecturer in Finance

Department of Business Administration

Green University of Bangladesh

Dhaka, Bangladesh

E-mail: mahadihasan15@yahoo.com

Md. Saiful Islam

Lecturer in Finance

Department of Business Administration

Bangladesh University

Dhaka, Bangladesh

Email: saiful5108@gamil.com

Md. Mahmudul Alam

Postgraduate student

Institute for Environment and Development (LESTARI)

National University of Malaysia (UKM)

Selangor, Malaysia

Email: rony000@gmail.com

\section{Citation Reference:}

Murad, M.W., Hasan, M.M., Islam, M.S., and Alam, M.M. 2014. Socio-Economic Profile Of The Low Income And Poor Communities In Kuala Lumpur City, Malaysia, International Journal of Ethics in Social Sciences, Vol. 2(1), pp. 113130. [Online Link]

This is a pre-publication copy.

The published article is copyrighted by the publisher of the journal.

\footnotetext{
${ }^{1}$ Corresponding author
} 


\begin{abstract}
It seems to have been apparent in developing nations that economic growth and urbanization are always interrelated. Malaysia's rapid economic growth has also resulted in a considerable growth of urbanization. As gleaned from the other side of the coin, the process of such urbanization had twisted numerous negative impacts on the socioeconomic aspects of the urban low income and poor communities living in the low-cost flats and squatters. One of the major impacts of Malaysia's rapid urbanization is the transformation in the socio-economic profile of the urban low income and poor communities. This paper aims to determine and analyze the socio-economic indicators affecting the profile of the urban low income and poor communities residing in the squatters and low-cost flats of Kuala Lumpur city, Malaysia. To pursue the objective, the study has conducted a field survey, collected primary data from the level of living conditions of the urban low income and poor households and has employed some statistical techniques such as descriptive statistics, analysis of variance (ANOVA), and the chi-square test. The empirical findings of this study appeared to have important policy implications and are expected to enable the respective policy and decision makers in their effort to alleviate urban poverty.
\end{abstract}

Keywords: Socio-economic profile, urban low income and poor communities, urban poverty, and Kuala Lumpur City.

\title{
INTRODUCTION
}

Following rapid economic development and population growth in Kuala Lumpur city in the last few years, numerous issues arose pertaining to the causes of urbanization in the city. Several of these issues and causes are seem to have been unusual and specific only to Kuala Lumpur city. The reasons are many folds, such as its strategic location, topography, history and the manner in which developments have been planned and implemented. However, our study reveals that some of the issues are common to many cities in developing Southeast Asia region and are therefore applicable to them as well. Malaysia has experienced spectacular urban spatial transformations from 1970 to 1997. During this period, Malaysia's national development strategies were structured around urban-based industrial growth. This in turn, not only increased urban units but also brought about an expansion of the existing urban centers outwards leading to an expansion of the urban boundaries. This expansion is mainly in response to the increasing number of people coming to settle in the urban areas due to their economic hardship in the rural areas. Moreover, Malaysia's economic downturn in 1998 also pushed a substantial number of low-income people out of the formal sector not only for employment, but also for housing. To many of them, rents became too high and lowincome housing areas were simply too far from their workplace. So, driven out of formal housing markets by high prices, distance to workplace, cost of transport, and other relevant factors, the urban low income and poor communities have been settled on the government or private individual lands. In fact, these lands are not suitable for healthy and livable settlements as environmental disadvantages like steep slopes, hazardous waste landfills, high pollution from the factories, and proximity of floods are always involved in these are protected ecological areas. Thus, the urban poor, who are generally referred to as squatter households and low-cost flat dwellers, tend unintentionally to degrade the environment. In fact, squatter settlements are almost always illegal and also common in most countries of developing Asia. Various studies revealed that the Malaysian 
population is increasingly urbanized. From about a quarter of the total population who were "urban" in 1970, the total number increased to about half of the population in 1991. The level rose to about 55 percent in 1995 and was then expected to be more than 60 percent in the year 2005 (Seventh Malaysia Plan 1996). Several factors have contributed to the increase in the urban low-income and poor communities since 1980s. Among these factors, rural-to-urban and urban-to-urban migrations and the economic crisis are significant.

The growth of Kuala Lumpur city has been largely generated by a rapid increase in population. Poverty and economic hardships in rural areas combined with stimulate out-migration from rural to urban areas. Because, the urban economic base, supported by the expansion in the manufacturing and construction sectors, trade, commerce, finance, and transportation networks has enabled the urban population to enjoy higher incomes and a better quality of lifestyles than their rural counterparts. During the Seventh Malaysia Plan (1996-2000), the average monthly urban household income has increased by 14.6 percent per annum, compared to the average monthly rural household income that has increased by 13.0 percent. Reflecting this, urban population was increased by 3.8 percent per annum during the Seventh Malaysia Plan, against the total population growth by 2.1 percent.

However, the much-discussed issue that followed due to the rapid urbanization in the Kuala Lumpur city is squatter settlements. In Kuala Lumpur, squatter settlements were first observed during the economic depression of the late twenties and early thirties (Simon and Khoo 1976). By 1970, the number of squatters in Kuala Lumpur was estimated to be about 103,370. The number has subsequently increased to 243,154 in 1978 (Abdullah 1987). Following the efforts by the City Hall of Kuala Lumpur to resettle the squatters in low-cost flats, their number decreased to 220,055 in $1982,156,151$ in 1985, and to 129,129 in 1998 representing a substantial percentage (about 17 percent) of the total population of Kuala Lumpur City (Bureau of Consultancy 1998). Although the number of squatters in Kuala Lumpur declined, the number is on the increase in other areas of the Klang Valley (Petaling Jaya, Gombak, Hulu Langat, and Klang).

In Kuala Lumpur, most of the squatters and low-cost flats are characterized by the absence or lack of basic infrastructure services such as waste disposal, sanitation, water supply, sewerage and drainage, roads, health care, education centers etc. and are exposed to fire, floods, and other natural disasters (Razak 1996). Since squatter sites are generally underserved with public amenities and basic needs, these invariably become potential sites for various types of environmental degradation. Squatter dwellings are generally made of discarded materials such as scraps of used wooden planks, bits of plastic, corrugated metal, asbestos sheeting, and even cardboard. Population densities in such communities are high and malnutrition is often widespread. Inadequate waste management, water supply, and sanitation facilities result in a high incidence of environmental diseases amongst the squatter households.

There are also other problems such as lack of cleanliness in the living area and congested living conditions observed in the squatters and low-cost flat areas, which result in the squatters and low-cost flat households' living unhealthy. Due to the lack of sanitation facilities and waste disposal sites, wastes are often thrown into Klang River and other places. Although 58.9 percent of squatters have proper sanitation facilities, 41.1 percent are still using the traditional methods of sanitation (Razak 1996). This together with the improper method of waste disposal puts the urban low income and poor communities at a high risk of contracting infectious diseases. Many endemic diseases such as diarrhea, typhoid, food poisoning and infant mortality are common amongst the 
urban poor. In addition, the cramped conditions in which they live mean that communicable disease such as influenza and tuberculosis can be easily transmitted.

However, this study is thought to be an important effort, which may enable policy and decision makers in their attempt to alleviate urban poverty. The author is very much optimistic that determining and analyzing the socio-economic indicators affecting the profile of the urban low income and poor communities, who are usually deprived of the basic amenities of life, could help alleviating urban poverty.

\section{MATERIALS AND METHODS}

\section{Sources of Data and Sample Design}

The analysis of this study is based on primary data collected recently from three areas of squatters and low-cost flats in Kuala Lumpur city. The data for this study were taken to reflect the current socio-economic profile of the urban low income and poor communities, particularly squatters and low-cost flat dwellers. Therefore the squatters and low-cost flat areas were chosen for the field survey. Trained interviewers paid their visits for several times in each study area. The interviewers had conducted the interviews with the persons who were the heads of the households, the wives or persons responsible for the economic decision for their families, and older than 18 years.

The overall sampling design for the study can be described as "stratified quota random sampling" with the key stratification variable "characteristics of household". In the first stage, the households to be surveyed had been selected purposively through a preliminary "windshield survey" in which the general characteristics of squatters or lowcost flats were found to exist. For doing this, enumerators were assigned to particular household types in each area, with minimum interview-quotas for each household-type. Then, to interject randomness into the sampling plan, enumerators had been advised to seek interviews with every second or third home on a particular street. A total of 300 household heads were interviewed from three parliamentary areas of Kuala Lumpur within which 100 households were selected from each area following the ratio of sixty percent and forty percent for the squatters and low-cost flats respectively.

\section{Study Area Selection}

The study was undertaken in three parliamentary areas of the Federal Territory of Kuala Lumpur. The parliamentary areas are Kepong, Segambut, and Titiwangsa and the respective squatter areas that have been surveyed are Jinjang Utara Tambahan, Sentul Pasar, and Datuk Keramat. It has been observed that most of the low-cost flats are situated at the places other than squatters and most of these are also scattered. Although a substantial number of low-cost flats are located at Jinjang Utara Tambahan that fulfilled the requirement of the sample size ratio of the study but their distribution was scattered in both Datuk Keramat and Sentul Pasar. However, there have been two low-cost flats selected from the area of Sentul Pasar, namely Flat Sri Terengganu and Flat Sri Kelantan. Sentul Pasar is an area that was considered within the broader boundary of Sentul Utara. To collect data in accordance with sample size ratio, three low-cost flats have also been selected from Datuk Keramat area. The selected low-cost flats are Flat Pangsa Murni, Flat Seri Perlis 2, and Flat Keramat Jaya and these three flats are located at the center place of Datuk Keramat area. 


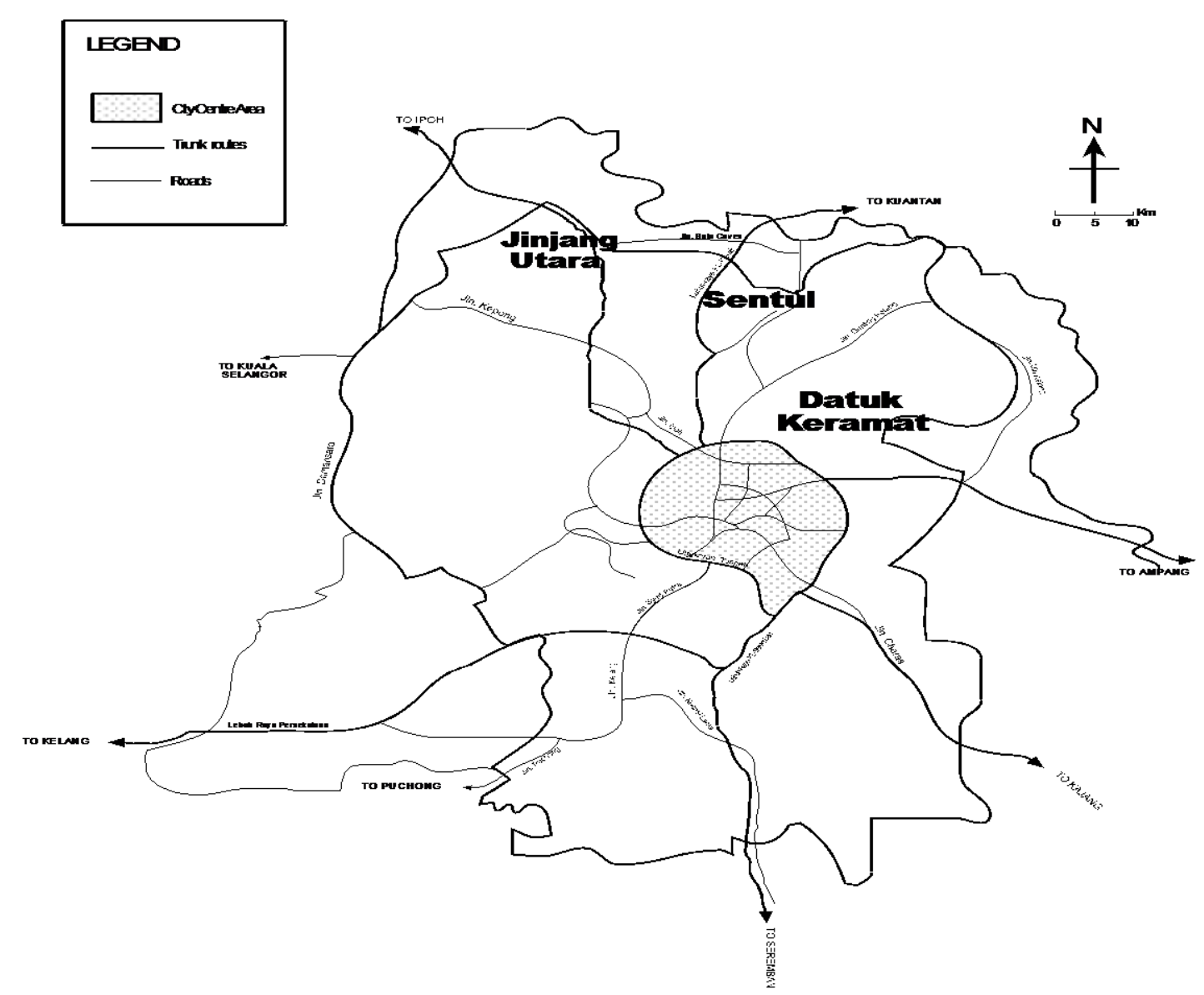

Figure 1: Map showing the location of the three study areas in Kuala Lumpur city in which the study was undertaken.

Two initial criteria prompted the researcher to select these three areas. First, the poor groups residing within the federal territory of Kuala Lumpur were predominantly concentrated in the squatter areas. In addition, a considerable number of the urban low income and poor communities had also been living in the low-cost flats. Therefore, in order to identify the actual information on the poverty threshold, squatters and low-cost flats were chosen. Second, the study focuses on 'multi-cultural diversity' that is comprised of the several ethnic groups, such as Malay, Chinese, and Indian.

Moreover, to interject all the ethnic groups into the study three different squatter and low-cost flat areas were selected with the view that an individual ethnic group must be dominant in each area. From this point of view, three areas of squatters and low-cost flats were selected within which an individual ethnic group was found to be dominant. The study covered such areas from Kuala Lumpur city in which Chinese were found to be the most dominant group in Jinjang Utara Tambahan while Indians and Malays were found to be the most dominant group respectively in Sentul Pasar and Datuk Keramat.

\section{Questionnaire Preparation}

In order to collect primary data from the urban low income and poor communities, a structured questionnaire was developed iteratively over time. The final changes in the questionnaire were made based on observations and results of pre-testing the final draft questionnaire. The original questionnaire was prepared in the Malay language. A relatively large proportion of respondents in Jinjang Utara and Sentul were more fluent in languages other than Malay. For this reason, multi-lingual enumerators had been engaged 
for these two areas and those interviews were conducted in languages most familiar to individual respondents. Since the second most common language is English, the original questionnaire was further translated into English to enable English-friendly respondents to answer. In cases of Mandarin, Cantonese, and Tamil; enumerators translated questions 'on the spot', which were further verified by the researchers.

\section{Technique of Analysis}

At the first stage of data analysis, descriptive statistics such as means, ranges, and frequency distributions have been computed for all variables in the questionnaire and for selected variables for use in multivariate analysis. Three types of statistical tests determined the statistical significance of three types of differences between and among variables. For example, the significance of differences for continuous variables between pairs of means has been tested by "t-tests of equality of means" and the significance between more than two means such as differences among the three areas has been tested by one-way analysis-of-variance (ANOVA) tests. In addition, the significance of differences for discrete variables between and among observed and expected frequencies has been examined by Chi-square "likelihood ratio" tests.

\section{RESULTS AND DISCUSSION \\ Respondents' Gender Status}

The respondents (urban low-income and poor communities in the present study) of this study were the heads of households, the wives, and the persons responsible for the economic decisions, and older than eighteen years of age. The study conducted interviews mainly with male householders, fathers or husbands (77.3 percent of respondents), followed by female householders, mothers or wives (22.7 percent) (Table 1). The role of respondents in the family differs significantly among areas $(\mathrm{P}<0.01)$, with fathers or husbands were playing larger relative role in each area (Jinjang Utara 89.0 percent, Sentul 71.0 percent, and Datuk Keramat 72.0 percent). Among the female respondents, mothers or wives being most common in both Sentul (29.0 percent) and Datuk Keramat (28.0 percent), but their roles were reported less noticeable in Jinjang Utara (11.0 percent). 
Table 1: Socio-economic indicators of the urban low income and poor communities within individual areas.

\begin{tabular}{|c|c|c|c|c|c|}
\hline \multirow{2}{*}{\multicolumn{2}{|c|}{ Socio-economic Indicators }} & \multicolumn{4}{|c|}{ Area } \\
\hline & & \multirow{3}{*}{$\begin{array}{c}\begin{array}{c}\text { Jinjang } \\
\text { Utara }\end{array} \\
89.0\end{array}$} & \multirow{2}{*}{$\begin{array}{r}\text { Sentul } \\
\text { Per } \\
\end{array}$} & \multirow{2}{*}{$\begin{array}{c}\text { Datuk } \\
\text { Keramat } \\
\text { cent }\end{array}$} & \multirow{2}{*}{ Total $^{* * * *}$} \\
\hline & & & & & \\
\hline \multirow{2}{*}{ Gender } & Male & & 71.0 & 72.0 & 77.3 \\
\hline & Female & 11.0 & 29.0 & 28.0 & 22.7 \\
\hline \multirow{5}{*}{$\begin{array}{l}\text { Age group (in } \\
\text { years) }\end{array}$} & $\leq 18$ & 0.0 & 0.0 & 0.0 & 0.0 \\
\hline & $19-30$ & 11.0 & 11.0 & 20.0 & 13.9 \\
\hline & $31-45$ & 49.0 & 60.0 & 44.0 & 51.2 \\
\hline & $46-64$ & 40.0 & 29.0 & 35.0 & 34.6 \\
\hline & $\geq 65$ & 0.0 & 0.0 & 1.0 & 0.3 \\
\hline \multirow{7}{*}{$\begin{array}{l}\text { Highest } \\
\text { educational } \\
\text { qualification }\end{array}$} & No Schooling & 10.0 & 15.0 & 4.0 & 9.7 \\
\hline & Primary School & 42.0 & 33.0 & 23.0 & 32.7 \\
\hline & SRP/LCE & 32.0 & 25.0 & 29.0 & 28.7 \\
\hline & SSC/SPM/MCE & 10.0 & 20.0 & 27.0 & 19.0 \\
\hline & HSC/STPM & 6.0 & 0.0 & 5.0 & 3.7 \\
\hline & Diploma & 0.0 & 6.0 & 10.0 & 5.3 \\
\hline & First Degree & 0.0 & 1.0 & 2.0 & 1.0 \\
\hline \multirow{12}{*}{$\begin{array}{l}\text { Income range } \\
\text { (Per month, per } \\
\text { household) }\end{array}$} & MYR (1-600) & 0.0 & 3.0 & 3.0 & 2.0 \\
\hline & MYR (601-1200) & 0.0 & 17.0 & 27.0 & 14.7 \\
\hline & MYR (1201-1500) & 36.0 & 6.0 & 16.0 & 19.3 \\
\hline & MYR (1501-2000) & 47.0 & 19.0 & 28.0 & 31.3 \\
\hline & MYR (2001-2500) & 0.0 & 18.0 & 10.0 & 9.3 \\
\hline & MYR (2501-3000) & 7.0 & 12.0 & 6.0 & 8.3 \\
\hline & MYR (3001-3500) & 4.0 & 8.0 & 4.0 & 5.3 \\
\hline & MYR (3501-4000) & 0.0 & 6.0 & 2.0 & 2.7 \\
\hline & MYR (4001-4500) & 6.0 & 3.0 & 0.0 & 3.0 \\
\hline & MYR (4501-5000) & 0.0 & 2.0 & 2.0 & 1.3 \\
\hline & MYR (5001-6000) & 0.0 & 2.0 & 1.0 & 1.0 \\
\hline & > MYR 6000 & 0.0 & 4.0 & 1.0 & 1.7 \\
\hline \multirow{4}{*}{ Ethnic group } & Malay & 0.0 & 0.0 & 98.0 & 32.7 \\
\hline & Chinese & 100.0 & 0.0 & 0.0 & 33.3 \\
\hline & Indian & 0.0 & 100.0 & 0.0 & 33.3 \\
\hline & Others & 0.0 & 0.0 & 2.0 & 0.7 \\
\hline \multirow{4}{*}{ Marital status } & Married & 89.0 & 83.0 & 86.0 & 86.0 \\
\hline & Single/Unmarried & 3.0 & 11.0 & 7.0 & 7.0 \\
\hline & Divorced & 0.0 & 3.0 & 6.0 & 3.0 \\
\hline & Widow & 8.0 & 3.0 & 1.0 & 4.0 \\
\hline \multirow{3}{*}{$\begin{array}{l}\text { Home } \\
\text { ownership } \\
\text { tenure } \\
\end{array}$} & Own & 88.0 & 42.0 & 53.0 & 61.0 \\
\hline & Rent & 12.0 & 51.0 & 45.0 & 36.0 \\
\hline & Others & 0.0 & 7.0 & 2.0 & 3.0 \\
\hline \multirow{4}{*}{ Occupation } & Private Sector & 57.0 & 35.0 & 46.0 & 46.0 \\
\hline & Government Sector & 0.0 & 26.0 & 16.0 & 14.0 \\
\hline & Private Business & 26.0 & 12.0 & 9.0 & 15.7 \\
\hline & Retired & 4.0 & 12.0 & 11.0 & 9.0 \\
\hline
\end{tabular}




\begin{tabular}{llcccc}
\hline \hline \multirow{2}{*}{ Socio-economic Indicators } & \multicolumn{4}{c}{ Area } \\
\cline { 3 - 6 } & & $\begin{array}{c}\text { Jinjang } \\
\text { Utara }\end{array}$ & Sentul $\begin{array}{c}\text { Datuk } \\
\text { Keramat }\end{array}$ & Total $^{* * * *}$ \\
\cline { 2 - 6 } & Others & \multicolumn{4}{c}{ Percent } \\
\hline \multirow{2}{*}{ Work status } & Permanent & 73.0 & 15.0 & 18.0 & 15.3 \\
& Temporary & 30.0 & 15.0 & 87.0 & 80.7 \\
\hline \hline
\end{tabular}

Note: *** Indicate significant difference among areas at 0.01 level.

Age of Respondents

The average age of survey respondents is 42.2 years, with the average in Jinjang Utara (43.4 years) not significantly higher than that in either Sentul (41.9 years) or Datuk Keramat (41.3 years). However, in each area, as well as for all respondents in the study, the age ranges differ significantly among areas $(\mathrm{P}<0.01)$, with the most common age ranges are 31-45 years (51.2 percent), 46-64 years (34.6 percent), and 19-30 years (13.9 percent) (Table 1).

\section{Educational Attainment of Respondents}

The most common highest level of education obtained by all 300 respondents in the survey is Primary School (32.7 percent), followed by "SRP/LCE" (28.7 percent), and "SPM/MCE" (19.0 percent) (Table 1). It is worth noting here that in Malaysia SRP stands for Sijil Rendah Pelajaran (in Malay language), which can be translated into English as Lower Certificate of Education (LCE). Moreover, SPM stands for Sijil Pelajaran Malaysia (in Malay language), which can be translated into English as Malaysian Certificate of Education (MCE). The Secondary School Certificate (SSC) in Malaysia is considered equivalent to both SPM and MCE. Of the all respondents, a total of 9.7 percent were found with the education level of "No Schooling". However, levels of education differ significantly among areas $(\mathrm{P}<0.01)$, with the most common highest levels obtained in Jinjang Utara are 42.0 percent "primary School" and 32.0 percent "SRP/LCE". In Sentul, the most common highest levels obtained by respondents are 33.0 percent "Primary School", 25.0 percent "SRP/LCE", and 20.0 percent "SPM/MCE". The most common highest education levels obtained by respondents in Datuk Keramat are 29.0 percent "SRP/LCE", followed by 27.0 percent "SPM/MCE", and 23.0 percent "Primary School".

\section{Educational Attainment of Respondents' Household Members}

It is reasonably expected that the socio-economic profile should also consider the level of education of all members of a household than on that for just the one household member or household head. For this reason, consideration has also been given to provide response to the question on education of all household members. In the present study, the average number of members fitting into each education level category in the various households for each area has been determined (Table 2). Although these average numbers have no real meaning in life rather they are only abstract numbers. But the tests of differences among them reveal significant meanings of the fact. Among the surveyed households in Jinjang Utara, compared to those in the other two areas, a significantly greater presence $(\mathrm{P}<0.01)$ of lower level of education from pre-school up to SRP/LCE and a significantly lesser presence $(\mathrm{P}<0.01)$ of degrees more advanced than SPM/MCE.

Table 2: Highest Educational Qualification Obtained by Household Members.

\begin{tabular}{|c|c|c|c|c|}
\hline \multirow{2}{*}{ Level of Education } & Jinjang Utara & Sentul & Datuk Keramat & Total \\
\hline & \multicolumn{4}{|c|}{ Mean Number } \\
\hline $\begin{array}{l}\text { Not Yet Entered } \\
\text { School }\end{array}$ & 0.9000 & 0.3000 & 0.7000 & $0.6333^{* * *}$ \\
\hline
\end{tabular}




\begin{tabular}{|c|c|c|c|c|}
\hline \multirow{2}{*}{ Level of Education } & Jinjang Utara & Sentul & Datuk Keramat & Total \\
\hline & \multicolumn{4}{|c|}{ Mean Number } \\
\hline No Schooling & 0.5200 & 0.7400 & 0.6100 & $0.6233^{\mathrm{NS}}$ \\
\hline Pre-School & 0.6800 & $9.000 \mathrm{E}-02$ & 0.6800 & $0.4833^{* * *}$ \\
\hline Primary School & 1.5800 & 2.0700 & 1.0900 & $1.5800^{* * *}$ \\
\hline SRP/LCE & 2.0400 & 1.3800 & 0.7900 & $1.4033^{* * *}$ \\
\hline SPM/MCE & 0.6300 & 1.0400 & 0.9100 & $0.8600^{* *}$ \\
\hline STPM/HSC & $6.000 \mathrm{E}-02$ & $2.000 \mathrm{E}-02$ & 0.1900 & $9.000 \mathrm{E}-02^{* * *}$ \\
\hline Diploma & 0.0000 & 0.2000 & 0.2800 & $0.1600^{* * *}$ \\
\hline First Degree & 0.0000 & $5.000 \mathrm{E}-02$ & $6.000 \mathrm{E}-02$ & $3.667 \mathrm{E}-02 *$ \\
\hline Post-Graduate Degree & 0.0000 & 0.0000 & $1.000 \mathrm{E}-02$ & $3.333 \mathrm{E}-03^{\mathrm{NS}}$ \\
\hline
\end{tabular}

Note:

*** Indicate significant at $\mathrm{P}<0.01$ level.

** Indicate significant at $\mathrm{P}<0.05$ level.

* Indicates significant at $\mathrm{P}<0.10$ level.

NS Indicates not significant at $\mathrm{P} \geq 0.10$ level.

\section{Monthly Total Household Income}

The average income of respondents is MYR 947.00 with the average in Sentul (MYR 983.50) not significantly higher than that in either Jinjang Utara (MYR 944.20) or Datuk Keramat (MYR 914.04). But, the average total household income is MYR 2102.56 with the average in Sentul (MYR 2,536.50) significantly higher $(\mathrm{P}<0.01)$ than that in both Jinjang Utara (MYR 1,952.20) and Datuk Keramat (MYR 1,818.99). In each area, as well as for all households in the study, the most common ranges of total household income per month reported for the all households surveyed are MYR 1,501-2,000 (31.3 percent of households), MYR 1,201-1,500 (19.3 percent of households), and MYR (601-1,200 (14.7 percent of households) (Table 1). On the other hand, 9.3 percent of respondents reported that their monthly household income range is MYR 2,001-2,500, while 8.3 percent indicated the range to be MYR 2,501-3,000, and only 1.7 percent of respondents reported that of equals MYR 6,000 or more. Levels of household income differ significantly among areas $(\mathrm{P}<0.01)$, with the most common ranges are 47.0 percent of MYR 1,5012,000, 36.0 percent of MYR 1,201-1,500, 7.0 percent of MYR 2,501-3,000, and 6.0 percent of MYR 4,001-4,500 in Jinjang Utara. In Sentul, the most common ranges of households' income are 19.0 percent of MYR 1,501-2,000, 18.0 percent of MYR 2,0012,500, 17.0 percent of MYR 601-1,200, and 12.0 percent of MYR 2,501-3,000. For Datuk Keramat, the ranges are 28.0 percent of MYR 1,501-2,000, 27.0 percent of MYR 6011,200, 16.0 percent of MYR 1,201-1,500 and, 10.0 percent of MYR 2,001-2,500.

\section{Households' Economic Status}

The monthly household incomes are clearly much higher on average in Sentul than in both Jinjang Utara and Datuk Keramat. Moreover, the total incomes for households surveyed in each area are heavily concentrated in lower-income ranges. Although the official poverty line income for Peninsular Malaysia is MYR 510 per month/per household, the government also uses the income level of less than or equals MYR 1,200 for determining the low-income households that are eligible for assistance from government. Using this income level as a measure for Kuala Lumpur City, a total of 16.7 percent of households in all the three areas can be categorized as low-income group within which 2.0 percent can also be categorized as very poor (using the poverty line 
income of less than or equals MYR 600) (Table 1). The highest number of low-income households was found in Datuk Keramat (30.0 percent) followed by 20.0 percent in Sentul. But, the households that can be categorized as either low-income group or very poor were not found in Jinjang Utara. However, while using the income level of less than or equals MYR 1,500 as a measure for determining the number of low-income group in Kuala Lumpur City, a total of 36.0 percent of all the surveyed households can be categorised as low-income group. The highest number of low-income group of households was found in Datuk Keramat (46.0 percent) while their number was found to be the lowest in Sentul (26.0 percent). The second highest number of low-income group of households was found in Jinjang Utara (36.0 percent).

\section{Respondents' Ethnic Group}

Of all the respondents interviewed, 32.7 percent are Malay, 33.3 percent Chinese, 33.3 percent Indian and only 0.7 percent other (Table 1). Since the selection of three study areas was done with the view that an individual ethnic group should be dominant in an area and the percentage of respondents interviewed in each area should also be the same the 300 respondents in the present study have an over-representation of each ethnic group. However, the ethnic mix differs significantly among areas $(\mathrm{P}<0.01)$, with both Chinese and Indian communities (100.0 percent each) by far the most dominant group in Jinjang Utara and Sentul respectively, and Malays (98.0 percent of respondents) the main group in Datuk Keramat.

\section{Association Between Ethnic Group and Monthly Household Income}

The association between ethnic group and monthly household income is statistically significant $(\mathrm{P}<0.01)$ (Table 3). Malays generally report lower monthly incomes as 29.6 percent of households in ranges up to MYR 1,200, 45.0 percent in the range of MYR $1,201-2,000,10.0$ percent in the range of MYR 2,001-2,500, and only 15.0 percent are in the range of greater than MYR 2,500. No Chinese households reported having the total income of less than MYR 1,200, but their monthly total incomes (37.0 percent up to MYR 1,500, 46.0 percent up to MYR 2,000, and 17.0 percent in the range of greater than MYR 2,500) are slightly lesser than those for the Indians (45.0 percent up to MYR 2,000, 30.0 percent in the range of MYR 2,001-3,000, and 25.0 percent in the range of greater than MYR 3,000). The income ranges for Indian households are distributed across a wide span from lower up to the higher income ranges (20.0 percent of households' incomes are less than MYR 1,200 and 4.0 percent more than MYR 6,000).

Table 3: Association between Respondents' Ethnic Group and Monthly Household Income.

\begin{tabular}{lccccc}
\hline \multirow{2}{*}{$\begin{array}{l}\text { Range in Monthly } \\
\text { Household Income }\end{array}$} & \multicolumn{5}{c}{ Ethnic Group } \\
\cline { 2 - 6 } & Malay & Chinese & Indian & Others & Total $^{* * * *}$ \\
\hline MYR (1 - 600) & 3.1 & 0.0 & 3.0 & 0.0 & 2.0 \\
MYR (601 - 1200) & 26.5 & 0.0 & 17.0 & 50.0 & 14.7 \\
MYR (1201 - 1500) & 16.3 & 36.0 & 6.0 & 0.0 & 19.3 \\
MYR (1501 - 2000) & 28.6 & 47.0 & 19.0 & 0.0 & 31.3 \\
MYR (2001 - 2500) & 10.2 & 0.0 & 18.0 & 0.0 & 9.3 \\
MYR (2501 - 3000) & 6.1 & 7.0 & 12.0 & 0.0 & 8.3 \\
MYR (3001 - 3500) & 3.1 & 4.0 & 8.0 & 50.0 & 5.3 \\
MYR (3501 - 4000) & 2.0 & 0.0 & 6.0 & 0.0 & 2.7 \\
MYR (4001 - 4500) & 0.0 & 6.0 & 3.0 & 0.0 & 3.0 \\
MYR (4501 - 5000) & 2.0 & 0.0 & 2.0 & 0.0 & 1.3 \\
MYR (5001 - 6000) & 1.0 & 0.0 & 2.0 & 0.0 & 1.0 \\
More than MYR 6000 & 1.0 & 0.0 & 4.0 & 0.0 & 1.7
\end{tabular}




\begin{tabular}{lrrrrr}
\multicolumn{1}{c}{ Total } & 100.0 & 100.0 & 100.0 & 100.0 & 100.0 \\
\hline Note: & & & &
\end{tabular}

\section{Association between Ethnic Group and Education Level of Respondents}

The association between ethnic group and education level of respondents is statistically significant $(\mathrm{P}<0.01)$ (Table 4). Chinese respondents generally have an average lower level of education with 10.0 percent having no education, 42.0 percent primary school, 32.0 percent SRP/LCE, 10.0 percent SPM/MCE, 6.0 percent STPM/HSC, and no respondent reported having education level higher than STPM/HSC. More than fifty-three percent of Malay respondents have an education level of between primary school and SRP/LCE, 27.6 percent SPM/MCE, and more than 14.0 percent between STPM/HSC and Diploma. As many as 52.0 percent of Indian households have an average education level of SRP/LCE or greater, 33.0 percent primary school, and 15.0 percent no education. It is further worth noting here that education levels of Higher Secondary Certificate (HSC) and Diploma in Malaysia are not very different, as Higher Secondary Certificate and Diploma need 12 and 12.5 years of schooling time respectively. Higher Secondary Certificate is the norm as the majority of colleges and higher learning institutions offer the qualification while the Diploma is offered only by some of these institutions, namely higher colleges and universities.

Table 4: Association between Ethnic Group and Highest Educational Qualification of Respondents.

\begin{tabular}{|c|c|c|c|c|c|}
\hline \multirow{3}{*}{$\begin{array}{c}\text { Highest Educational } \\
\text { Qualification }\end{array}$} & \multicolumn{5}{|c|}{ Respondents' Ethnic Group } \\
\hline & Malay & Chinese & Indian & Others & Total $^{* * * *}$ \\
\hline & \multicolumn{5}{|c|}{ Percent } \\
\hline No Schooling & 3.1 & 10.0 & 15.0 & 50.0 & 9.7 \\
\hline Primary School & 23.5 & 42.0 & 33.0 & 0.0 & 32.7 \\
\hline SRP/LCE & 29.6 & 32.0 & 25.0 & 0.0 & 28.7 \\
\hline SPM/MCE & 27.6 & 10.0 & 20.0 & 0.0 & 19.0 \\
\hline STPM/HSC & 5.1 & 6.0 & 0.0 & 0.0 & 3.7 \\
\hline Diploma & 9.2 & 0.0 & 6.0 & 50.0 & 5.3 \\
\hline First Degree & 2.0 & 0.0 & 1.0 & 0.0 & 1.0 \\
\hline Total & 100.0 & 100.0 & 100.0 & 100.0 & 100.0 \\
\hline
\end{tabular}

\section{Association between Respondents' Family Size and Income and Education}

The average total number of household members is 5.86 with differences among areas in total household numbers statistically significant at "P $<0.01$ " level (Table 5). Within the youngest and middle age groups comprising households, however, differences among areas are also statistically significant $(\mathrm{P}<0.01)$. But, the differences involving the age group of 55 years or more within individual areas are not statistically significant $(\mathrm{P} \geq$ $0.10)$. The association between family size and monthly household income is statistically significant $(\mathrm{P}<0.01)$, with an upright patterned relationship with income (Table 6). For example, households in the low levels of income ranges of less than or equals MYR 1,200 and MYR 1,201-1,500 are below average in size but, households in the all other income ranges indicate an increasing number of above-average in size. The association between 
family size and education level of household heads is generally inverse and statistically significant $(\mathrm{P}<0.05)$ (Table 7). For example, household heads having an education level of between "no schooling" and "primary school" are comprised of an average of 6.01 family members, whereas household heads having a higher education level of STPM/HSC are comprised of an average 5.09 family members. However, household heads with an education level of between "SRP/LCE" and "diploma" or higher do not fit with the generally direct patterned relationship between family size and education level, because their average size is about 6.0 persons. 
Table 5: Size of Household and Age of Household Members within Ethnic Groups.

\begin{tabular}{|c|c|c|c|c|c|}
\hline \multirow[t]{2}{*}{ Age Group } & $\begin{array}{c}\text { Jinjang } \\
\text { Utara }\end{array}$ & \multicolumn{2}{|c|}{ Sentul } & $\begin{array}{l}\text { Datuk } \\
\text { Keramat }\end{array}$ & Total \\
\hline & \multicolumn{5}{|c|}{ Mean Number } \\
\hline $\begin{array}{l}\text { Number of children in the family } \\
\text { aged below } 14 \text { years }\end{array}$ & 2.83 & \multicolumn{2}{|c|}{1.54} & 1.89 & $2.09^{* * * *}$ \\
\hline $\begin{array}{l}\text { Number of family members aged } 15- \\
54 \text { years }\end{array}$ & 3.10 & \multicolumn{2}{|c|}{3.94} & 2.95 & $3.33^{* * *}$ \\
\hline $\begin{array}{l}\text { Number of family members aged } \\
\text { between } 55 \text { years or more }\end{array}$ & 0.48 & \multicolumn{2}{|c|}{0.40} & 0.48 & $0.45^{\mathrm{NS}}$ \\
\hline \multirow[t]{2}{*}{ Average Size } & 6.41 & 5.89 & & 5.28 & $5.86^{* * *}$ \\
\hline & \multicolumn{5}{|c|}{ Ethnic Group } \\
\hline \multirow[t]{2}{*}{ Age Group } & Malay & Chinese & Indian & Others & Total \\
\hline & \multicolumn{5}{|c|}{ Mean Number } \\
\hline $\begin{array}{l}\text { Number of children in the family } \\
\text { aged below } 14 \text { years }\end{array}$ & 1.86 & 2.83 & 1.54 & 3.00 & $2.09^{* * *}$ \\
\hline $\begin{array}{l}\text { Number of family members aged } 15- \\
54 \text { years }\end{array}$ & 2.95 & 3.10 & 3.94 & 3.00 & $3.33^{\text {*** }}$ \\
\hline $\begin{array}{l}\text { Number of family members aged } \\
\text { between } 55 \text { years or more }\end{array}$ & 0.46 & 0.48 & 0.40 & 1.00 & $0.45^{\mathrm{NS}}$ \\
\hline Average Size & 5.25 & 6.41 & 5.89 & 7.0 & $5.86^{\text {*** }}$ \\
\hline
\end{tabular}

Note:

*** Indicate significant at $\mathrm{P}<0.01$ level.

NS Indicates not significant at $\mathrm{P} \geq 0.10$ level.

Table 6: Association between Family Size Measured in Discrete Terms and Monthly Household Income.

\begin{tabular}{|c|c|c|c|c|c|c|c|c|c|c|c|c|}
\hline & \multicolumn{12}{|c|}{ Range in Monthly Household Income (In MYR) } \\
\hline & $\leq \mathbf{1 2 0 0}$ & $\begin{array}{c}1201- \\
1500 \\
\end{array}$ & $\begin{array}{c}1501- \\
2000 \\
\end{array}$ & $\begin{array}{l}2001- \\
2500 \\
\end{array}$ & $\begin{array}{c}\text { 2501- } \\
3000 \\
\end{array}$ & $\begin{array}{l}\text { 3001- } \\
\text { 3500 } \\
\end{array}$ & $\begin{array}{c}3501- \\
4000 \\
\end{array}$ & $\begin{array}{c}4001- \\
4500 \\
\end{array}$ & $\begin{array}{r}4501- \\
5000 \\
\end{array}$ & $\begin{array}{c}5001- \\
6000 \\
\end{array}$ & $>6000$ & Total \\
\hline $\begin{array}{l}\text { Number of } \\
\text { family } \\
\text { members }\end{array}$ & 4.44 & 5.25 & 6.17 & 6.21 & 6.04 & 8.06 & 6.50 & 6.44 & 7.50 & 6.00 & 8.00 & $5.86^{* * *}$ \\
\hline
\end{tabular}

Table 7: Association between Average Family Size Measured in Discrete Terms and Level of Education of Respondents.

\section{Level of Education}

\begin{tabular}{ll}
\hline No Schooling & 6.6552 \\
Primary School & 5.3673 \\
SRP/LCE & 6.1977 \\
SPM/MCE & 5.9474 \\
STPM/HSC & 5.0909 \\
Diploma & 5.8750
\end{tabular}


First Degree

Note:

** Indicate significant at $\mathrm{P}<0.05$ level.

Association between Type of House and Monthly Household Income and Education of Respondents

Of all respondents in the study, 60.0 percent were interviewed from squatters and 40.0 percent from low-cost flats. The determination of respondents being interviewed from squatters and low-cost flats was done purposively to cover a wide variety of low-income and poor communities. However, housing types covered in the survey differ not significantly among areas $(\mathrm{P} \geq 0.10)$, as the types of houses were also selected purposively using the same percentages of respondents interviewed from each study area. House type and monthly household income are significantly associated $(\mathrm{P}<0.05)$ (Table $8)$. Those living in squatters have the relatively lowest average income $(71.5$ percent squatter households have a maximum monthly income of MYR 2,000), followed by those living in low-cost flats (60.8 percent low-cost flat dwellers have a maximum monthly income of MYR 2,000). In addition, 37.0 percent low-cost flat households reported that they have the medium-average monthly income (which falls within the range of MYR 2,001-6,000) followed by the squatter households (27.4 percent in the same income range). House type and education level of household heads are also significantly associated $(\mathrm{P}<0.05)$ (Table 9). For example, the household heads with an education level of SRP/LCE or less occupy 75.6 percent of squatter houses, while 64.2 percent low-cost flats have been reported to be occupied by the household heads having the same education level.

Table 8: Association between Type of House and Monthly Household Income.

\begin{tabular}{lccc}
\hline \hline \multirow{2}{*}{\begin{tabular}{c} 
Range in Monthly Household \\
\cline { 2 - 4 }
\end{tabular}} & Squatter & Low-cost Flat & Total $^{*}$ \\
\cline { 2 - 4 } & \multicolumn{3}{c}{ Percent } \\
\hline RM (1 - 600) & 2.8 & 0.8 & 2.0 \\
RM (601 - 1200) & 16.1 & 12.5 & 14.7 \\
RM (1201 - 1500) & 22.8 & 14.2 & 19.3 \\
RM (1501 - 2000) & 30.0 & 33.3 & 31.3 \\
RM (2001 - 2500) & 10.0 & 8.3 & 9.3 \\
RM (2501 - 3000) & 7.8 & 9.2 & 8.3 \\
RM (3001 - 3500) & 3.3 & 8.3 & 5.3 \\
RM (3501 - 4000) & 1.1 & 5.0 & 2.7 \\
RM (4001 - 4500) & 3.9 & 1.7 & 3.0 \\
RM (4501 - 5000 & 1.1 & 1.7 & 1.3 \\
RM (5001 - 6000) & 0.0 & 2.5 & 1.0 \\
More than RM 6000 & 1.1 & 2.5 & 1.7 \\
Total & 100.0 & 100.0 & 100.0 \\
\hline \hline
\end{tabular}

Note:

* Indicates significant at $\mathrm{P}<0.10$ level. 
Table 9: Association between Type of House and Highest Educational Qualification of Respondents.

\begin{tabular}{|c|c|c|c|}
\hline \multirow{3}{*}{ Highest Educational Qualification } & \multicolumn{3}{|c|}{ Type of House } \\
\hline & Squatter & Low-cost Flat & Total ${ }^{* *}$ \\
\hline & \multicolumn{3}{|c|}{ Percent } \\
\hline No Schooling & 12.2 & 5.8 & 9.7 \\
\hline Primary School & 36.7 & 26.7 & 32.7 \\
\hline SRP/LCE & 26.7 & 31.7 & 28.7 \\
\hline SPM/MCE & 17.2 & 21.7 & 19.0 \\
\hline STPM/HSC & 4.4 & 2.5 & 3.7 \\
\hline Diploma & 2.2 & 10.0 & 5.3 \\
\hline First Degree & 0.6 & 1.7 & 1.0 \\
\hline Total & 100.0 & 100.0 & 100.0 \\
\hline
\end{tabular}

Note:

** Indicate significant at $\mathrm{P}<0.05$ level.

\section{Respondents' Home Ownership Tenure}

Sixty-one percent of all respondents live in owned homes and 36.0 percent in rented homes (Table 1). Percentages differ significantly among areas $(\mathrm{P}<0.01)$, with the incidence of renting being greatest in Sentul (51.0 percent) followed by 45.0 percent in Datuk Keramat, and least in Jinjang Utara (12.0 percent). The incidence of home ownership is found to be highest in Jinjang Utara (88.0 percent) followed by 53.0 percent in Datuk Keramat and least in Sentul (42.0 percent).

\section{Occupation of Respondents}

A total of forty-six percent of household heads work in the private sector (Table 1), followed by 14.0 percent in the government sector. About 16 percent have their own private businesses, 9.0 percent are retired, and the remaining (more than 15 percent) household heads are involved in "other" types of works. Among areas, occupation of household heads differs significantly $(\mathrm{P}<0.01)$. Compared to other areas, Jinjang Utara has no government sector employees, but the most are either private sector employees (57.0 percent) or private business operators (26.0 percent). On the other hand, Sentul has the highest number of government sector employees (26.0 percent), while the lowest numbers of employees (35.0 percent) are reported to be working with the private sector. In Datuk Keramat, the average number of household heads (46.0 percent) is reported to be working with the private sector followed by 18.0 percent are engaged in "other" types of works, 16.0 percent with the government sector, 11.0 percent are retired, and 9.0 percent are involved with private business operations.

\section{Association Between Nature of Employment of the Household Head and Monthly Household Income}

The nature of employment of the household heads and monthly household income are significantly related $(\mathrm{P}<0.01)$ (Table 10$)$. The household heads working with the government sector are significantly contributing to a middle level of total household income (38.0 percent in the range of MYR 2,001-4,500 and an additional 2.4 percent more than MYR 6,000) followed by those having their private businesses are significantly contributing to the lower-middle level of total household income (32.0 percent in the range of MYR 2,001-3,500 and only an additional 4.2 percent more than MYR 3,500). The income range where the highest numbers of households are concentrated is less than or equals MYR 1,200. For example, nearly 72.0 percent of household heads engaged in "other" types of work are significantly contributing to the lowest level of total household 
income (less than or equals MYR 2,000) followed by those working in the private sector (70.0 percent), private businesses (63.8 percent), retired (63.0 percent), and government sector (60.0 percent). However, for all the occupation categories, the highest percentages of total household income were in the range of MYR 1,501-2,000 (retired 37.0 percent, private sector 34.8 percent, private business 34.0 percent, government sector 31.0 percent, and others 13.0 percent).

Table 10: Association between Nature of Employment of Heads of Households and Monthly Household Income.

\begin{tabular}{lcccccc}
\hline \hline & \multicolumn{5}{c}{ Main Occupation of Respondents } \\
\cline { 2 - 7 } Range in Monthly & $\begin{array}{c}\text { Private } \\
\text { Household Income }\end{array}$ & $\begin{array}{c}\text { Government } \\
\text { Sector }\end{array}$ & $\begin{array}{c}\text { Private } \\
\text { Business }\end{array}$ & Retired & Others & Total $^{* * * *}$ \\
\cline { 2 - 7 } & \multicolumn{7}{c}{ Percent } \\
\hline RM (1 - 600) & 0.7 & 2.4 & 0.0 & 3.7 & 6.5 & 2.0 \\
RM (601 - 1200) & 13.8 & 14.3 & 4.3 & 14.8 & 28.3 & 14.7 \\
RM (1201 - 1500) & 20.3 & 11.9 & 25.5 & 7.4 & 23.9 & 19.3 \\
RM (1501 - 2000) & 35.5 & 31.0 & 34.0 & 37.0 & 13.0 & 31.3 \\
RM (2001 - 2500) & 8.0 & 9.5 & 17.0 & 11.1 & 4.3 & 9.3 \\
RM (2501 - 3000) & 11.6 & 9.5 & 4.3 & 7.4 & 2.2 & 8.3 \\
RM (3001 - 3500) & 3.6 & 7.1 & 10.6 & 7.4 & 2.2 & 5.3 \\
RM (3501 - 4000) & 2.2 & 9.5 & 0.0 & 0.0 & 2.2 & 2.7 \\
RM (4001 - 4500) & 0.0 & 2.4 & 0.0 & 3.7 & 15.2 & 3.0 \\
RM (4501 - 5000 & 1.4 & 0.0 & 2.1 & 3.7 & 0.0 & 1.3 \\
RM (5001 - 6000) & 0.7 & 0.0 & 0.0 & 3.7 & 2.2 & 1.0 \\
More than RM 6000 & 2.2 & 2.4 & 2.1 & 0.0 & 0.0 & 1.7 \\
\multicolumn{1}{c}{ Total } & 100.0 & 100.0 & 100.0 & 100.0 & 100.0 & 100.0 \\
\hline \hline
\end{tabular}

Note:

$* * *$ Indicate significant at $\mathrm{P}<0.01$ level.

Association Between Nature of Employment and Education Level of the Household Heads

The nature of employment and level of education of household heads are significantly related $(\mathrm{P}<0.01)$ (Table 11). The two employment categories with the highest level of education are government servants $(62.0$ percent of household heads are having the education level of between primary school and SRP/LCE, 36.0 percent are above SRP/LCE, and 2.0 percent are below the primary school) and private employees (nearly 60.0 percent of household heads are having education level of between primary school and SRP/LCE, more than 33.0 percent are above SRP/LCE, and 7.0 percent are below the primary school). The average level of education for household heads in the private business and "retired" or "others" category does not show any similarity with one another. However, nearly 28.0 percent of private business household heads have an educational level of above SRP/LCE, 68.0 percent between primary school and SRP/LCE, and more than 4.0 percent with "no schooling". About 18.5 percent of household heads in retired category have an educational level of above SRP/LCE, 77.8 percent between primary school and SRP/LCE, and 3.7 percent with "no schooling". The distribution of household heads in other category is more than 17.0 percent above SRP/LCE, 50.0 percent between primary school and SRP/LCE, and 32.6 percent with "no schooling".

Table 11: Association between Nature of Employment and Highest Educational Qualification of Household Heads.

Highest Nature of Employment




\begin{tabular}{|c|c|c|c|c|c|c|}
\hline \multirow[t]{2}{*}{$\begin{array}{l}\text { Educational } \\
\text { Qualification }\end{array}$} & $\begin{array}{l}\text { Private } \\
\text { Sector }\end{array}$ & $\begin{array}{c}\text { Government } \\
\text { Sector } \\
\end{array}$ & $\begin{array}{c}\text { Private } \\
\text { Business }\end{array}$ & Retired & Others & Total ${ }^{* * *}$ \\
\hline & \multicolumn{6}{|c|}{$\begin{array}{lr} & \text { Percent } \\
\end{array}$} \\
\hline No Schooling & 7.2 & 2.4 & 4.3 & 3.7 & 32.6 & 9.7 \\
\hline Primary School & 33.3 & 16.7 & 29.8 & 63.0 & 30.4 & 32.7 \\
\hline SRP/LCE & 26.1 & 45.2 & 38.3 & 14.8 & 19.6 & 28.7 \\
\hline SPM/MCE & 22.5 & 31.0 & 8.5 & 14.8 & 10.9 & 19.0 \\
\hline STPM/HSC & 2.2 & 2.4 & 14.9 & 0.0 & 0.0 & 3.7 \\
\hline Diploma & 8.0 & 2.4 & 4.3 & 3.7 & 2.2 & 5.3 \\
\hline First Degree & 0.7 & 0.0 & 0.0 & 0.0 & 4.3 & 1.0 \\
\hline Total & 100.0 & 100.0 & 100.0 & 100.0 & 100.0 & 100.0 \\
\hline
\end{tabular}

\section{Respondents' Work Status}

Of all household heads interviewed, 82.7 percent are full-time workers and 17.3 percent are part-time workers. The numbers of full-time and part-time workers do not differ significantly among areas $(\mathrm{P} \geq 0.10)$, with the highest number of full-time workers (87.0 percent) in Datuk Keramat, followed by 81.0 percent in Sentul, and 80.0 percent in Jinjang Utara. The incidence of part-time workers is highest in number in Jinjang Utara (20.0 percent) followed by 19.0 percent in Sentul, and 13.0 percent in Datuk Keramat. Besides, more than 80.0 percent household heads are doing permanent work while 19.3 percent temporary job (Table 1). The type of work differs significantly among areas $(\mathrm{P}<$ $0.01)$, with the highest number of permanent workers (87.0 percent) in Datuk Keramat, followed by 85.0 percent in Sentul, and 70.0 percent in Jinjang Utara. On the other hand, the highest incidence of temporary workers was reported in Jinjang Utara (30.0 percent) followed by 15.0 percent in Sentul and 13.0 percent in Datuk Keramat.

\section{Household Income Earning Members}

Of all households surveyed, 46.3 percent have two full-time income-earning workers, 19.7 percent three full-time workers, 11.7 percent four full-time workers, and 18.0 percent one full-time worker (Table 12). The mean number of income-earning workers per household is 2.40 , with household means differing significantly among areas $(\mathrm{P}<$ 0.01). The highest mean of income-earning workers was detected 2.80 in Sentul followed by 2.34 in Jinjang Utara and 2.06 in Datuk Keramat.

Table 12: Number of Income Earning Members in Household within Individual Areas and Ethnic Groups.

\begin{tabular}{ccccc}
\hline \hline \multirow{2}{*}{$\begin{array}{c}\text { Number of Earning } \\
\text { Members }\end{array}$} & $\begin{array}{c}\text { Jinjang } \\
\text { Utara }\end{array}$ & Sentul & $\begin{array}{c}\text { Datuk } \\
\text { Keramat }\end{array}$ & Total $^{* * *}$ \\
\cline { 2 - 5 } & \multicolumn{4}{c}{ Percent } \\
\hline 1.00 & 16.0 & 9.0 & 29.0 & 18.0 \\
2.00 & 52.0 & 37.0 & 50.0 & 46.3 \\
3.00 & 20.0 & 27.0 & 12.0 & 19.7 \\
4.00 & 6.0 & 22.0 & 7.0 & 11.7 \\
5.00 & 6.0 & 3.0 & 1.0 & 3.3 \\
6.00 & 0.0 & 1.0 & 0.0 & 0.3 \\
7.00 & 0.0 & 1.0 & 0.0 & 0.3 \\
8.00 & 0.0 & 0.0 & 1.0 & 0.3 \\
Total & 100.0 & 100.0 & 100.0 & 100.0 \\
& & & &
\end{tabular}




\begin{tabular}{|c|c|c|c|c|c|}
\hline Ave & & 2.34 & 2.80 & 2.06 & 2.40 \\
\hline \multirow{3}{*}{$\begin{array}{c}\text { Earning } \\
\text { Members }\end{array}$} & \multicolumn{5}{|c|}{ Ethnic Group } \\
\hline & Malay & Chinese & Indian & Others & Total $^{* * *}$ \\
\hline & \multicolumn{5}{|c|}{ Mean Score } \\
\hline Average & 2.04 & 2.34 & 2.80 & 3.00 & 2.40 \\
\hline
\end{tabular}

\section{Respondents' Marital Status}

Of all respondents interviewed, 86.0 percent are married, 7.0 percent single or unmarried, 4.0 percent widow, and 3.0 percent are divorced (Table 1). The marital status of respondents differs significantly among areas $(\mathrm{P}<0.01)$, with the highest married persons reported in Jinjang Utara (89.0 percent), followed by 86.0 percent in Datuk Keramat and 83.0 percent in Sentul. Single or unmarried respondents have the highest incidence in Sentul (11.0 percent) followed by 7.0 percent in Datuk Keramat and 3.0 percent in Jinjang Utara. No divorced respondent was detected in Jinjang Utara, but this incidence is highest in Datuk Keramat (6.0 percent) followed by 3.0 percent in Sentul. The incidence of widow respondents is highest in Jinjang Utara ( 8.0 percent) followed by 3.0 percent in Sentul and 1.0 percent in Datuk Keramat.

\section{POLICY IMPLICATIONS AND CONCLUDING COMMENTS}

This empirical research has determined and analyzed the socio-economic indicators affecting the profile of the urban poor residing in the squatters and low-cost flats of Kuala Lumpur city, Malaysia. These factors, however, could guide us to recommend numerous policy implications, which would really play dynamic roles in building the quality of lifestyles for the urban poor, particularly the squatters and low-cost flat dwellers. It is expected that the policy implications of this study might be useful for the appropriate authority of the three study areas, i.e., Kuala Lumpur City Hall, which is locally known as Dewan Bandaraya Kuala Lumpur (DBKL). Depending on the degree to which current socio-economic profile and cultural features of respondents in the three parliamentary areas are similar to those in other parliamentary areas, the policy implications might have a wider applicability. It is also reasonably expected that the policy implications of this study would be useful to policy and decision-makers of appropriate authority in their efforts to alleviate poverty amongst the urban poor and low-income communities.

This empirical study has been proven to be significant in terms of its inherent objective. In fact, an improvement in profile of the urban poor classes means a reduction in poverty, which could lead the country towards achieving sustainable economic development. Malaysia is the world's most fastest developing nation with the concurrent improvement of macro fundamentals and her own economic infrastructure. It has built a national vision of 2020 by which the country is determined to be enlisted among the developed nations. It is obvious that such a supreme goal needs serious orientation to improve the profile of the urban poor and low-income communities. Therefore, the following implications have been made to support the government in materializing its dream:

\section{Education Goal}

An increase in the education level of the urban poor is an important condition to increase their income and to improve their socio-economic profile. The government can take a pragmatic measure by setting up technical schools/colleges specifically to train the urban squatters and low-cost flat dwellers in scientific waste disposal systems, systems of cleanliness and house-keeping systems to create more employment opportunities in municipalities, hotels-motels, offices and restaurants. Furthermore, graduates of this 
academic system can directly be absorbed in the government-sponsored health and hygiene programs, cleanliness and waste disposal management systems.

\section{Removal of Regional Disparity}

The results of the study show that the respondents living in this area of Sentul enjoy better job and income earning opportunities (Table 1). It was observed in the study that the area of Sentul is closer to the city center and thus its residents enjoy urban city infrastructure and facilities. While the other two places are far away from the city center resulting in discrimination of development and income disparity. Removing regional disparity is an essence of modern development to create equitable income earning opportunities for the urban poor and low-income groups. Other two areas should also be given similar infrastructure facilities. For transforming a country into a fully developed nation, there is no alternative to the removal of regional disparity. Infrastructure developments in all populated areas must be expedited with adequate academic, training, income potentials and other social developments to reclassify the status of the urban poor and low-income groups. Malaysia, as a fastest developing nation, has been emphasizing priorities on faster infrastructure developments around its populated territories.

\section{Head of Household Registration and Development}

The government could take up a head of household registration program for the urban poor and low-income communities to put them in governmental development programs including education, training, and employment opportunities as the income of the household heads has a positive and significant influence on socio-economic profile of a household. Therefore, creating better opportunities for the household heads under sophisticated governmental and private programs may bring a sustainable quality of lifestyles to these urban poor and low-income groups. Reaching higher quality of lifestyles is important not only in terms of higher income opportunities but also to reduce wasteful situations, communicable diseases, crimes etc. It would further ensure the education of their children and influence families to make savings and create asset-bases. It has been observed that the government has already taken good initiative by constructing long housing of small flats to accommodate these urban poor, particularly the squatter inhabitants.

\section{Family Size to Be Treated as Income Opportunities}

The results of the study have proven that the association between family size and monthly household income is statistically significant $(\mathrm{P}<0.01)$, with an upright patterned relationship with income (Table 6). The most interesting point of this empirical study is that this finding is evidenced against the general economic theory, which postulates an inverse relationship between household income level and family size that was described by the classical economists, such as, Malthus (1798) and later by neo-classical scholars such as Kuznets (1989). However, it can be argued here that family size is important in developing nations especially for the poor and low-income groups to improve earning potentials. It does not necessarily mean to increase the number of family members by overwhelming childbirth by the poor, rather the emergence on the part of the government to support the families with higher family size to further improve their profile and income opportunities. One of the observable reasons of high income of the large family size is that the economic necessity may have seriously pushed the household heads to innovate additional income-earning opportunities and forced the other members of the family to earn income in order to meet the basic needs of the families. Additional government support may improve the profile of the urban poor, particularly in some other socioeconomic indicators such as reducing the likelihood of child-labor, ensuring schooling of their children, enabling parents to be involved in family matters and increasing the likelihood of savings, capital, investments, and asset-base. These measures may be 
termed as an exploration of a society, which could contribute largely to the country's national income.

\section{Spouse Income as a Source of Development}

The descriptive results of the study give evidence to the effect that income received from spouse has a significant and positive relationship to the total household income. Beside the family roles, spouses of the urban poor and low-income groups may take part in additional income opportunities. A government initiative to include more non-earning spouses in the income generating activities may help support the families greatly. This would further generate the economic capabilities of the urban poor resulting in the enhancement of their purchasing power, savings, and investments that could further lead to improve macro-fundamental characteristics of the country's economy.

\section{Skill Development Issues}

It is evidenced in the study that the age of the head of households has a significant and positive relationship to the household income level. It has exactly coincided with the already established economic theory that the older is the heads of households the greater will be their income earning capacity and hence higher income level. It can be argued here that the older household heads usually be able to earn more than their younger counterparts for various reasons such as they are more skilled, knowledgeable and literate. The government may nurture their skills further to provide them with skill development training, scientific measures and tools to use in the modern society in the areas of waste management system, methods of disinfections, systems to curbing contagious diseases, environmental protection programs, gardening, horticulture and agricultural projects, cleanliness and housekeeping programs etc.

In conclusion, poverty seems to be dangerous for a country not only in terms of incapacity of productive people but also the risk of environmental degradations. Human Settlements Program of International Institute for Environment and Development (IIED) writes in their briefing paper (2001) "at least 600 million of these (urban dwellers) have income and asset bases too low to cover the cost of essentials, and live in homes and neighborhoods with such poor quality, overcrowded housing and inadequate services that their lives and health are continually at risk".

It is reasonably expected that the poor could be rich and their socio-economic profile will then improve if rigorous attention is given on their needs. Economic richness provides capabilities to the human beings and broadens the scope of social knowledge, maturity, and consciousness when resources are available to meet the demands. It also contributes to the understanding of social justice and social responsibilities, which are most essential factors for real development. In this era of economic interdependence, countries around the world seem not to have been overpoweringly engaged in alleviating poverty. Engagement in alleviating poverty could have been a greatest effort in nondiscriminatory developmental process and equitable distribution of income. Principles of welfare economics could have been in place to foster the development promptly. Viewing the study area, Kuala Lumpur City Hall (DBKL), a government authority, has already taken some pragmatic measures to improve the socio-economic profile of the urban poor such as, resettlement of squatters in long houses and other programs. For example, Kuala Lumpur City Hall has established squatters upgrading program to provide assistance to the urban poor and improve their quality of life. Under this program, government and non-governmental organizations had jointly carried out various projects and activities. Health provisions, pre-school education for children and a maternal and child health clinic have been provided throughout the squatter areas in Kuala Lumpur city. The program has successfully solved some of the health and socio-economic problems of squatter residents (Agus 1997). However, the findings of this empirical study would still 
be useful for the appropriate authority in their effort to take up several affirmative policies leading to improve the socio-economic profile of urban low income and poor communities. Income, education, training, living standards, health care, environmental protection, and other urban facilities must be improved in order to improve the socioeconomic profile. Moreover, it is inherent in the subject of any development that the updated technology, technological means, technology transfers, and scientific methods must be put in place to empower the urban poor workforce in building their own capabilities. Beside the government, private and non-governmental organizations could play a significant role to guide the urban poor in the transition to develop their skills, income, and capabilities. Such productivity drive could enlighten the essence of true development of an urbanized society. 


\section{REFERENCES}

Abdullah, H. 1987. Squatter communities along the Klang river: A general survey. In: Tropical urban ecosystems studies, Eds., Sham Sani, 2: 74-87. Kuala Lumpur: Department of Environment, Government of Malaysia.

Agus, M.R. 1997. Urban growth, poverty and the squatter phenomenon. In: Poverty amidst plenty - Research findings and the gender dimension in Malaysia. Eds., Jamilah Ariffin, 127-151. Kuala Lumpur: Pelanduk Publications.

Bureau of Consultancy. 1998. Re-census of squatters in Federal Territory of Kuala Lumpur 1998. Penang: Universiti Sains Malaysia, Final Report Prepared for Kuala Lumpur City Hall (DBKL).

International Institute for Environment and Development. 2001. Briefing paper no. 4. London: Human Settlements Program, International Institute for Environment and Development (IIED).

Kuznets, S.S. 1989. Economic development, the family and income distribution: selected essays. London: Cambridge University Press.

Malthus, T.R. 1798. An essay on the principle of population as it affects the future improvements of mankind. Reprint in 1976, New York: Norton Publishers.

Razak, N. 1996. Kemiskinan bandar: Pengalaman DBKL dalam menanganinya (In Malay) (Urban poverty: The role of Kuala Lumpur City Hall (DBKL) in overcoming the problem). Kuala Lumpur: Paper Presented in the Seminar on National Concern on Urban Poverty.

Seventh Malaysia Plan. 1996. Seventh Malaysia plan 1996 - 2000. Kuala Lumpur: Economic Planning Unit, Prime Minister's Department, Government of Malaysia.

Simon, F.V.M. and Khoo, K.K. 1976. The squatters as a problem to urban development: A historical perspective. Kuala Lumpur: Persatuan Ekonomi Malaysia, Paper Presented in the Third Economic Convention. 